\title{
Institutions and entrepreneurship: unidirectional or bidirectional causality?
}

\author{
Ali Hussein Samadi(i)
}

Correspondence:

asamadi@rose.shirazu.ac.ir

Department of Economics, Shiraz

University, Shiraz, Iran

\begin{abstract}
There are various studies on the role of institutional and non-institutional factors in developing the level and nature (or types) of entrepreneurship. In these studies, there have been no attention to the causal relationship between these variables, and the direction of the causality are considered unidirectional and from institutions to the entrepreneurship. Furthermore, the current studies have only investigated the role of institutional factors in developing entrepreneurship for the short-run and there was no attention for a long-run. Moreover, it should be noted that, this relationship is studied disregarding the level of the economic development of countries. Therefore, the main aim of this article is to investigate the causality between institutions and entrepreneurship regarding to the level of economic development (Factor-driven, Efficiency-driven and Innovation-driven countries) in both short and long term. The results show that the bidirectional causality between institutions and entrepreneurship is confirmed only in the innovation-driven countries, and only in the long-run.
\end{abstract}

Keywords: Institutions, Entrepreneurship, Causality, Development level, Short-run, Long-run

JEL classification: $\mathrm{K} 42, \mathrm{~K} 00$

\section{Introduction}

The concept of entrepreneurship was introduced by Richard Cantilon in 1755 . Since then, this term has been located at the center of academic analysis. Attention to this concept in the field of economics is related to the economists such as John S. Mill and Jean B. Say in the early 1800's. But in 1990, the seminal work of Baumol (1990) again caught more attention of academics to the various kinds of entrepreneurship and economics of entrepreneurship. Since then, numerous studies have been done theoretically and empirically on the factors affecting the level and types (or nature) of entrepreneurship. One of these factors is institutional factors. For a long period of time, it was believed that the institutional environment has an important impact on entrepreneurship.

Also, the fact that entrepreneurs can influence the institutional environment has been agreed upon by many economists, such as Schumpeter (1934). The general discussion of the theories of institutional economics is that entrepreneurs are the institutional change agents.

(c) The Author(s). 2019 Open Access This article is distributed under the terms of the Creative Commons Attribution 4.0 International License (http://creativecommons.org/licenses/by/4.0/), which permits unrestricted use, distribution, and reproduction in any medium, provided you give appropriate credit to the original author(s) and the source, provide a link to the Creative Commons license, and indicate if changes were made. 
On the other hand, economic growth is one of the reasons of the entrepreneurship development. In the literature on economic growth, institutions and entrepreneurship are two ultimate causes of the economic growth. So, we are facing to the triangle of institutions-entrepreneurship - economic growth. Now, the question is that: what is the relationship between institutions, entrepreneurship and economic growth? By resorting to various techniques, one can answer this question. Regression analysis (single equation and simultaneous equation system) is one of the techniques which is used in various studies. One of the basic pre-assumptions of regression analysis is that the direction of causality between the dependent and the independent variable (s) is given. In the vast majority studies in the area of the entrepreneurship economics - the institutional economics is assumed that entrepreneurship is the causes of institutional changes and/or institutional changes are the cause of entrepreneurship. Based on this, to investigate the effect of each variable on the other variables, regression analysis has been used. To the best knowledge of this researcher, studies which investigates the causal relationship between institutions and entrepreneurship have been ignored in existing studies. In the vast majority of studies (except Reddy, 2012), the relationship between these two variables has been investigated without any attention to the level of economic growth and development of countries. Recently, there have been few studies (e.g.: Henrekson and Sanandaji,2011; and Samadi, 2018) that discus or test the (bidirectional) causality between institutions and entrepreneurship. In these studies, although the causal relationship between these two variables is investigated as theoretically or on the base of the causality test, but the level of economic development of countries are ignored.

In examining the relationship between institutions and entrepreneurship, we can't ignore the level of economic development of countries and time horizon (short and long runs). Therefore, the one contribution of this paper is that the causality tests runs in Factor-driven, Efficiency-driven and Innovation-driven countries ${ }^{1}$ separately. And second contribution is that we have distinguished the short-run and long-run relationship between them.

The rest of the paper is organized as follows. Literature review is presented in Section 2. Theoretical background (the causal link between institutions and entrepreneurship) is discussed in section 3. In section 4, we discuss the methodology of the research. Section 5 is devoted to the analysis of the relationship between these variables in factor-driven, innovation-driven, and efficiency-driven countries. Section 6 is devoted to discussion. Section 7 concludes.

\section{Literature review}

In the literature of the entrepreneurship economics, various theories are presented to analysis the causes and factors affecting on the creation of opportunities, as well as the choice of entrepreneurial activities and will be examined as empirically (single country and panel). These theories seek to analysis the factors affecting on individual's choice to enter into entrepreneurial activities. One of these factors is institutions and the status of institutional quality. Also, in the literature of the institutional economics various theories are presented to illustrate factors influencing the process of institutional changes. One of the factors that recently have been highlighted in these texts is the activities of entrepreneurs. In this section, the empirical studies taken in these two strands briefly are reviewed. 
A myriad of studies has been devoted to explain the effects of the types of institutions on: level of entrepreneurship (e.g. Busenitz et al., 2000; Westlund and Bolton, 2003; Spencer and Gomez, 2004; Lee et al., 2007; Aidis et al., 2008; Nyström, 2008; Greener, 2009; Mitchell and Campbell, 2009; Stenholm et al., 2013; Simon-Moya et al. 2013; Urbano and Alvarez, 2014; Bastian et al., 2015; Castano et al., 2015; Williams and Vorley, 2015; Majbouri, 2016; and Elert et al., 2017) and types or natures of entrepreneurship (e.g. Baumol,1990; Stephen et al., 2005; Sobel, 2008; Bowen and De Clercq, 2008; El-Harbi and Anderson, 2010; Trolio, 2011; Stenholm et al., 2013; Valdez and Richardson, 2013; Dau and Cuervo-Cazurra, 2014; Sambharya and Musteen, 2014; Aparicio et al., 2015; Fuentelsaz et al., 2015; Muralidharan and Pathak, 2016; Fuentelsaz et al., 2018). These studies and other various studies in this field (both theoretically and empirically) have shown that the status of institutional quality is an important factor in order to expand the entrepreneurial activities and the possibility of entering toward this activity, in the countries under investigation.

On the other hand, a many studies, explain the role of entrepreneurial activities in the institutional change process (e.g. Kozul-Wright and Rayment, 1997; Yu, 2001; Baez and Abolafia, 2002; Greenwood and Suddaby,2006; Otahal, 2012; Kalantaridisa and Fletcher, 2012; and Kuchar, 2015; Fuentelsaz et al., 2015;). The general finding of these studies is that entrepreneurs are an important source to create institutional changes in countries, especially in developing countries. Although existing studies so far have investigated the relationship between entrepreneurship and institutional changes, but all of these studies ignore the causal link between these variables and causality direction assumed given.

According to the best of our knowledge, a few studies (e.g. Henrekson and Sanandaji, 2011; and Bjerregaard and Lauring,2012) explain the bidirectional causality between institutions and entrepreneurship, theoretically. The study conducted by Samadi (2018) is only empirical study in this area and for MENA countries. Samadi (2018) show that short-run causality only runs from entrepreneurship to institutional quality in MENA ${ }^{2}$ countries.

In few studies (e.g. Simon-Moya et al. 2013; Fuentelsaz et al. 2015; Aparicio et al. 2015; Angulo-Guerrero et al. 2017; Brixiova and Egert 2017; Samadi, 2018; and Fuentelsaz et al. 2018) the opportunity-driven and necessity-driven entrepreneurship (both or alone) are attention and the influence of institutional factors on their expansion. In these studies, panel data and/ or cross-sectional data has been used, and data from a specific region $\left(\mathrm{OECD}^{3}\right.$ countries, Latin American countries, MENA countries, ...) has been used.

Also there are studies that showed the relationship between entrepreneurship and institutions are dependent on the level of economic growth and development. The idea of the relationship between institutions and economic growth and entrepreneurial activities are presented by Wennekers and Thurik (1999). Acs et al. (2008) probed into the relationship between entrepreneurship and institutions to the level of economic development in a country. Reddy (2012) has comprehensive review of texts related to entrepreneurship and economic growth and development, entrepreneurship and institutions. After applying the configurational approach (suitable to use data from developed and developing countries in a panel data model as simultaneously) for 45 developed and developing countries during the period 2000-2007, the relationship 
between entrepreneurship and institutions to the level of economic development in a country is confirmed. This relationship also is confirmed by Youssef et al. (2018) for Africa.

To the best of this researcher's knowledge, an overview of existing studies shows that the causality relationship between entrepreneurship and institutions only is noted by Samadi (2018) as empirically and only for MENA countries (all countries are at the same level of development, and mainly are including of factor-driven countries). In the present study:

1. The level of development of countries is considered and causality tests run in factor-driven, efficiency-driven and innovation-driven countries separately.

2. We have distinguished the short-term and long-term causal relationship between institutions and necessity-driven and opportunity- driven entrepreneurship.

\section{Theoretical background}

There are various theories about the reasons of entering entrepreneurial activities and the expansion of entrepreneurship. From the view of these theories, the level and types of entrepreneurship are influenced by legal- economic, political, social, cultural, educational and managerial environments (Samadi, 2018, P. 63-64). The institutional environment is one of these environments, and nowadays there is high attention to this issue. On the other hand, there are several theories in the institutional economics about the causes of institutional change. The theory of entrepreneurial view of institutional change (Bjerregaard and Lauring, 2012; Henrekson and Sanandaji, 2011; Yu, 2001; Li et al., 2006; Kuchar, 2015; Henrekson, 2007; Samadi, 2018) is one of these theories and recently has attracted more attention in the literature. On the other hand, mutual relationship between institutions and institutional changes and entrepreneurship in the process of economic growth (Acs et al., 2008; Reddy, 2012) is a topic that has been at the center of attention for several years. Full description of these theories is not possible here, and a brief discussion is given below.

\section{Institutions are important}

According to the North (1990, P.19), institutions are rules of the game in the society. If rules of the game are such that profits are possible via unproductive activities, it is natural that entrepreneurs will have less incentive to enter productive activities and vice versa. Accordingly, Baumol (1990) divides entrepreneurship to three productive, unproductive and destructive types. Poor formal and informal institutions will strengthen opportunistic behaviors. Because the lack of clear rules of the game and resulting uncertainty, will make this incentive for people to use all opportunities in their benefit in every possible way. In such institutional environment, rent-seeking and corruption (unproductive and destructive entrepreneurship) will prevail productive activities (productive entrepreneurship).

In a poor institutional environment, the transfer of wealth (unproductive entrepreneurship) takes precedence. In most factor-driven countries, there are many economic and natural resources. But low institutional quality and poor structure of governing institutions are such that the countries could not take advantage of the benefits of entrepreneurship. Good quality of institutions reduces the profitability in activities related to 
the transfer and destruction of wealth (unproductive and destructive entrepreneurship) and increases it in activities related to the creation of new wealth (productive entrepreneurship) (Henrekson, 2007).

In countries with weak and insecure structure of property rights, there is no guarantee that benefits of investment and transactions as well as the result of the entrepreneurial activity is given to the entrepreneur (Samadi, 2008, 2018). In such an environment, there is the possibility of vertical expropriation. So the entrepreneur will not enter entrepreneurial activities likely and will spend his time and energy for other activities that are unproductive.

Generally, Institutional arrangements affect the profit and motivation of entrepreneurs (Simon-Moya et al. 2013). Therefore, institutions determine the level and types of entrepreneurship. In other words, there is a causal relationship from (types of) institutions to (types of) entrepreneurs. So:

Hypothesis 1: Institutional change causes entrepreneurship.

\section{Entrepreneurs are important}

Various theories have been proposed for institutional change. These theories can be categorized into Efficient Institutions view or political Coase theorem (PCT), Ideology or the Generalized PCT, The Incidental Institutions view, the social conflict view (see Acemoglu et al., 2003), Transaction cost theory of Institutional change, and entrepreneurial view of institutional change (Yu, 2001; Henrekson and Sanandaji, 2011; and Samadi, 2018). Yu (2001) by focusing on the theory of Schultz's human agency, Schumpeter's theory of economic responses, the theory of entrepreneurial discovery of Kirzner and utilizing the theory of some Austrian school economists, like Manger and Hayek, provided a new theory of the causes of an institutional change by entrepreneurs. He argues that ordinary and extraordinary discoveries of entrepreneurs have different effects. Ordinary discoveries improve production methods and adjust rules (adaptive response), but extraordinary discoveries damage the stability of institutions and thus create uncertainty in the market (creative response). When the stability of the institutions is lost, coordinating economic activities by institutions (one of their main tasks) will be difficult. Under such conditions, some actions are made in the society. Successful actions in the society are imitated and repeated and gradually manifested in new institutions. This institutional change, in fact, has been occurred due to the discovery of entrepreneurs. New institutions created (or changed) again play the role of coordinating economic activities of the society.

Henrekson and Sanandaji (2011) believe, entrepreneurs at least in three ways of abiding, evading and altering affect institutions. The researchers accordingly have presented a new classification of entrepreneurship as abiding entrepreneurship, evading entrepreneurship, and altering entrepreneurship. Entrepreneurs can accept existing institutions and challenge existing institutional basis (abide), evade them (evade), change and create new institutions with more effectiveness and/ or through innovative political activities change existing institutions (alter) directly.

The general view of the theory is that entrepreneurs are institutional change agents (North, 1990; Yu, 2001; Otahal, 2012; Troilo, 2011; Henrekson and Sanandaji, 2011; and Kuchar, 2015). In general, entrepreneurs in many ways can affect existing 
institutions, change and improve institutions ruling the market and other institutions. And therefore entrepreneurs are also important in the process of an institutional change and there is a causal relationship from (types of) entrepreneurs to (types of) institutions. So:

Hypothesis 2: entrepreneurship causes institutional change.

\section{Bidirectional causality}

If the quality of institutions is better in the society, productive entrepreneurship will be increased. Productive entrepreneurs, by creating new opportunities, provide new conditions facing political, policy, and institutional entrepreneurs. These entrepreneurs depending on the quality of institutions can strengthen or weaken the institutional quality. If there are institutions with high (low) quality, political entrepreneurs move to productive (unproductive) activities and strengthen (weaken) the quality of existing institutions.

As stated and examined theoretically by Henrekson and Sanandaji (2011, P.47), “ ... entrepreneurship is not only influenced by institutions - entrepreneurs often help shape institutions themselves... ". So there's a bidirectional causality:

Hypothesis 3: There is a bidirectional causality between entrepreneurship and institutional quality.

\section{Econometric methodology}

In this paper, a three-step methodology has been used. In the first step, a cross-sectional dependency test used to determine the cross-sectional dependency or independency. In the second step, based on the results of these tests, we can use some unit root tests. In the third step, after performing these tests, it will be determined that which model should be used to estimate a Granger-type causality test. If the variables are stationary, then we can use the level of variables, otherwise we can use the first or second difference of variables.

In the following the methodology used in this article briefly are explained.

\section{Cross-sectional dependency tests}

The general assumption in the panel data econometrics is that the data used are cross-sectional independent. This pre-assumption should be tested. There are various tests in the literature, including Friedman (1937), Breusch-Pagan LM (1980) and Pesaran's (2004) CD tests. Pesaran CD test has advantage compare to another tests including the high power for small samples and the applicable in balanced and unbalanced panel data. Also, against to the method of Breusch-Pagan LM (1980) for cross-sectional dimension $(\mathrm{N})$ and small dimensional time (T) provides credible results (Pesaran, 2004: 23). In the following a brief description of this test is presented.

The null and alternative hypothesis of Pesaran (2003) test for the balanced and unbalanced panel data are defined as eq. (1):

$$
\left\{\begin{array}{c}
H_{0}: \rho_{i j}=\rho_{j i}=E\left(u_{i t} v_{i t}\right)=0 \quad \text { for all } i \neq j \\
H_{i}: \rho_{i j}=\rho_{j i}=E\left(u_{i t} v_{i t}\right) \neq 0
\end{array}\right.
$$

Pesaran CD test statistics for balanced panel data is in the form of eq. (2): 


$$
\mathrm{CD}_{\text {balanced }}=\sqrt{\frac{2 \mathrm{~T}}{\mathrm{~N}(\mathrm{~N}-1)}}\left(\sum_{\mathrm{i}=1}^{\mathrm{N}-1} \sum_{\mathrm{j}=\mathrm{i}+1}^{\mathrm{N}} \hat{\rho}_{\mathrm{ij}}\right)
$$

and for unbalanced panel data is as eq. (3):

$$
\mathrm{CD}_{\text {unbalanced }}=\sqrt{\frac{2}{\mathrm{~N}(\mathrm{~N}-1)}}\left(\sum_{\mathrm{i}=1}^{\mathrm{N}-1} \sum_{\mathrm{j}=\mathrm{i}+1}^{\mathrm{N}} \sqrt{\mathrm{T}_{\mathrm{ij}}} \hat{\mathrm{\rho}}_{\mathrm{ij}}\right)
$$

where:

$$
\begin{aligned}
\hat{\rho}_{i j} & =\frac{\sum_{t \in\left(T_{i} \cap T_{j}\right)}\left(e_{i t}-\overline{\mathrm{e}}_{i}\right)\left(e_{j t}-\overline{\mathrm{e}}_{j}\right)}{\left[\sum_{t \in\left(T_{i} \cap T_{j}\right)}\left(e_{i t}-\bar{e}_{i}\right)^{2}\right]^{1 / 2}\left[\sum_{t \in\left(T_{i} \cap T_{j}\right)}\left(e_{j t}-\bar{e}_{j}\right)^{2}\right]^{1 / 2}} \\
\bar{e}_{i} & =\frac{\sum_{t \in\left(T_{i} \cap T_{j}\right)} e_{i t}}{\left(T_{i} \cap T_{j}\right)}
\end{aligned}
$$

$T_{i j}=\left(T_{i} \cap T_{j}\right)$ is the number of observations of the time series between units $i$ and $\left.j\right)$ and $\hat{\rho}_{\mathrm{ij}}$ is the Pearson's coupling correlation coefficients of residual.

If a $C D$ test statistic at a certain significant level is higher than the critical value of the normal standard distribution, it means that the null hypothesis is rejected and the Cross-Sectional dependence is concluded. Otherwise, there will be cross-sectional independence (Pesaran, 2004: 17).

\section{Panel unit root tests}

The appropriate unit root tests in balanced / unbalanced panel data are determined based on the results of cross-sectional dependence / independence tests. If there is a cross-sectional dependence on the panel data, should use Psara's CIPS unit root test and/or the cross-section Augmented Dickey-Fuller (CADF) test, and if there is cross-sectional independence, the and Im- Pesaran- Shin (IPS) unit root test, and/or Augmented Dickey-Fuller (ADF) should be used (Breitung and Pesaran, 2005: 9). Pesaran (2003) by converting ADF and IPS tests regarding to cross-sectional dependence, a test statistic has been proposed to examine the presence or absence of unit root that is known as the Pesaran CIPS Test. The test statistics of this test are shown in eq. (6):

$$
\operatorname{CIPS}\left(\mathrm{N}, \mathrm{T}_{\mathrm{i}}\right)=\mathrm{N}^{-1} \sum_{\mathrm{i}=1}^{\mathrm{N}} \mathrm{T}_{\mathrm{i}}\left(\mathrm{N}, \mathrm{T}_{\mathrm{i}}\right)
$$

$\mathrm{T}_{\mathrm{i}}\left(\mathrm{N}, \mathrm{T}_{\mathrm{i}}\right)$ is the test statistics of CADF for each individual section in the panel. The decision making rule about the existence or absence of the unit root is such that the amount of the test statistic is compared to the critical values calculated by the Pesaran, and if the magnitude of this statistic is greater than the critical values, the null hypothesis (not stationary) is rejected and the variable is stationary (Pesaran, 2004: 11).

\section{Panel causality test}

There are three alternative methods for causality testing. These three methods of testing are as follows: 
- conducting causality tests by I (1) variables and in the presence of cointegration.

- conducting causality tests by I (0) variables and in the presence of cointegration.

- -conducting causality tests by I (0) variables and in the absence of cointegration (Granger's test).

Testing method for each of the three methods is different. In the following, a brief explanation of the first method is presented.

Using the I (1) variables, the panel vector autoregressive (PVAR) model for the two variables entrepreneurship (Entre) and quality of institutions (Insti) can be written as eqs. 7 and 8:

$$
\begin{aligned}
& \text { Entre }_{i t}=a_{1}+\sum_{j=1}^{n+1} \mathrm{~b}_{1 \mathrm{j}} \text { Entre }_{i, t-j}+\sum_{j=1}^{n+1} c_{1 j} \text { Insti }_{i, t-j}+\varepsilon_{1 i t} \\
& \text { Insti }_{i t}=a_{2}+\sum_{\mathrm{j}=1}^{\mathrm{n}+1} \mathrm{~b}_{2 \mathrm{j}} \text { Entre }_{\mathrm{i}, \mathrm{t}-\mathrm{j}}+\sum_{\mathrm{j}=1}^{\mathrm{n}+1} \mathrm{c}_{2 \mathrm{j}} \text { Entre }_{\mathrm{i}, \mathrm{t}-\mathrm{j}}+\varepsilon_{2 \mathrm{it}}
\end{aligned}
$$

where $\mathrm{i}$ represents the sections (countries), and $\mathrm{t}$ indicates the time (years of study). Also, $\varepsilon_{1}$ and $\varepsilon_{2}$ are residuals term and $\mathrm{a}, \mathrm{b}$, and $\mathrm{c}$ are parameters of the PVAR model.

If there is a cointegration relationship between the variables, the error correction term (ECT) can drive by estimating the cointegration regression models of eqs. 9 and 10:

$$
\begin{aligned}
& \text { Entre }_{i t}=\alpha_{1 i}+\beta_{1 i} t+\mu_{1 i} \text { Insti }_{i t}+\varepsilon_{1 i t} \\
& \text { Insti }_{i t}=\alpha_{2 i}+\beta_{2 i} t+\mu_{2 i} \text { Entre }_{i t}+\varepsilon_{1 i t}
\end{aligned}
$$

ECT is a residual term from estimating these models. Based on the Granger representation theorem, and in a presence of cointegration relationship, we can model the dynamics of adjustment process of short-term and long-term simultaneously and the issue of short-term and long-term causality are investigated. To achieve this aim, the panel vector error correction model (PVECM) can be written as eqs. 11 and 12:

$$
\begin{aligned}
& \Delta \text { Entre }_{i t}=\sum_{j=1}^{n} \mathrm{~b}_{1 j} \Delta \text { Entre }_{i, t-j}+\sum_{j=1}^{n} \mathrm{c}_{1 j} \Delta \text { Insti }_{i, t-j}+d_{1} E C T_{i, t-1}+\Delta \varepsilon_{1 i t} \\
& \Delta \text { Insti }_{i t}=\sum_{j=1}^{n} \mathrm{~b}_{2 j} \Delta \text { Entre }_{i, t-j}+\sum_{j=1}^{n} \mathrm{c}_{2 j} \Delta \text { Entre }_{i, t-j}+d_{2} E C T_{i, t-1} \Delta \varepsilon_{2 i t}
\end{aligned}
$$

where $\Delta$ indicates the first order difference of the variables and $\mathrm{ECT}_{\mathrm{i}, \mathrm{t}-1}$ is the error correction term with lag (1). Also $\mathrm{n}$ and $\mathrm{m}$ are optimal lag length which are determined by some information criteria. According to the estimation of eqs. (11) and (12) and by the joint significance test of the coefficients of the endogenous variables and the coefficient of ECT can perform the short-term and long-term causality test. If the coefficient of ECT in eq. 11 (12) is statistically significant, it can be said that the institutions quality (entrepreneurs) is causes of entrepreneurship (institutional quality) in the long run. If two variables are significant $\left(d_{1}=d_{2} \neq 0\right)$, thus there is a bidirectional causality between two variables. But for diagnosis existence or lack of causality in the short-term between these variables, the hypotheses test of 13 and 14 should be done:

$$
\begin{aligned}
& H_{0}: c_{11}=c_{12}=\ldots=c_{1 n}=0 \\
& H_{0}: b_{21}=b_{22}=\ldots=b_{2 n}=0
\end{aligned}
$$

The alternative hypothesis in these cases is that at least one of the $c_{1 j}$ or $b_{2 j}$ is opposed to zero. If the null hypothesis of the 13 (14) is rejected, then institutions 
(entrepreneurs) is the causes of entrepreneurship (institutions). Otherwise, if the hypotheses 13 and 14 are rejected simultaneously, the direction of causality will be bidirectional.

\section{Empirical results}

\section{Data and some pretests}

To measure entrepreneurship, several indicators can be used. For opportunity-driven entrepreneurship (OE) in the literature Opportunity-Based Early-Stage Entrepreneurial Activity (Stephen et al., 2005; Acs and Amoros, 2008; Sambharya and Musteen, 2014; Valdez and Richardson, 2013; Aparicio et al., 2015; Castano et al., 2015; and Fuentelsaz et al., 2015), Total Early-Stage Entrepreneurial Activity (Wennekers et al., 2005; Levie and Autio, 2008; and Koellinger and Minniti, 2009) and Patent Grants (El Harbi and Anderson, 2010) and for necessity-driven entrepreneurship (NE), Necessity-Based Early-Stage Entrepreneurial Activity (Acs and Amoros, 2008; Valdez and Richardson, 2013; Sambharya and Musteen, 2014; and Fuentelsaz et al., 2015), Total Early-Stage Entrepreneurial Activity (Wennekers et al., 2005; and Autio and Acs, 2010) and Self-employment Rate (El Harbi and Anderson, 2010) indices are used. In this article, according to most of the previous studies, two indices of Necessity-Based Early-Stage Entrepreneurial Activity and Opportunity-Based Early-Stage Entrepreneurial Activity have been used. These data have been extracted from the $\mathrm{GEM}^{4}$ report. Also, the International Property Rights Index (Dedigama and Fellow, 2009; Storkova, 2010) and Heritage Freedom Index has been used for property rights variable.

Panel data were used for three groups of factor-driven countries ${ }^{5}$ in the period 20082014, and efficiency-driven ${ }^{6}$ and innovation-driven countries ${ }^{7}$ for the years $2005-2015 .^{8}$

The results show that ${ }^{9}$ there is cross-sectional independency between variables (Table 1). Also, all variables are nonstationary in all three groups of factor-driven, efficiency-driven and innovation-driven (Tables $2 \& 3$ ). The result of Pedroni cointegration test for all three group shows that all variables cointegrated. ${ }^{10}$

\section{Causality test}

To examine the hypothesis H1 (discussed in entrepreneurship literature), H2 (discussed in institutional economics literature), and H3 (proposed by Henrekson and Sanandaji, 2011), this paper uses variables of opportunity- driven and necessity-driven for entrepreneurship and variables of physical property rights, intellectual property rights, and international property rights index for institutions. Also, by using the Granger-type causality test, these hypotheses have been investigated for factor-driven, efficiency-driven and innovation-driven countries with panel data. The results of this test are presented in Table 4.

The results present in Table 4 show that in factor-driven countries there is a unidirectional causality from entrepreneurship to institutions in the short-run and long-run. This result points to the importance of attention to the entrepreneurship in these countries. Moreover, in efficiency-driven countries in short-run, entrepreneurship is the causes of institutions and in the long-run, institutions are the causes of entrepreneurship. But in the innovation-driven countries the results completely are different. In these countries, unlike the results obtained in factor-driven and efficiency-driven 
Table 1 Cross-Sectional Dependency Tests

\begin{tabular}{|c|c|c|c|c|c|}
\hline \multicolumn{2}{|l|}{ Test $\rightarrow$} & \multirow{2}{*}{$\begin{array}{l}\text { Breusch- } \\
\text { Pagan LM }\end{array}$} & \multirow{2}{*}{$\begin{array}{l}\text { Pesaran } \\
\text { scaled LM }\end{array}$} & \multirow{2}{*}{$\begin{array}{l}\text { Bias-corrected } \\
\text { scaled LM }\end{array}$} & \multirow{2}{*}{$\begin{array}{l}\text { Pesaran } \\
\mathrm{CD}\end{array}$} \\
\hline Variables $\downarrow$ & & & & & \\
\hline \multirow[t]{5}{*}{ Efficiency } & LIPR & $369.6(0.00)$ & $11.3(0.00)$ & $9.8(0.00)$ & $14.5(0.00)$ \\
\hline & LIPRI & $473.2(0.00)$ & $17.2(0.00)$ & $15.7(0.00)$ & $13.1(0.00)$ \\
\hline & LNEC & $245.5(0.00)$ & $4.25(0.00)$ & $2.75(0.00)$ & $0.4(0.66)^{*}$ \\
\hline & LOPP & $237.9(0.00)$ & $3.82(0.00)$ & $2.32(0.02)$ & $0.89(0.36)^{*}$ \\
\hline & LPPR & $404.9(0.00)$ & $13.3(0.00)$ & $11.8(0.00)$ & $8.3(0.00)$ \\
\hline \multirow[t]{5}{*}{ Factor } & LIPR & $18.9(0.21)$ & $-0.37(0.7)$ & $-0.87(0.3)$ & $2.7(0.00)$ \\
\hline & LIPRI & $27.1(0.03)$ & $1.2(0.26)$ & $0.6(0.5)$ & $-0.36(0.7)$ \\
\hline & LNEC & $22.6(0.09)$ & $0.3(0.7)$ & $-0.19(0.8)$ & $-0.14(0.8)$ \\
\hline & LOPP & $30.5(0.01)$ & $1.7(0.08)$ & $1.2(0.2)$ & $0.3(0.7)^{*}$ \\
\hline & LPPR & $21.7(0.11)$ & $0.12(0.8)$ & $-0.37(0.7)$ & $-0.67(0.4)$ \\
\hline \multirow[t]{5}{*}{ Innovation } & LIPR & $278.3(0.00)$ & $6.1(0.00)$ & $4.6(0.00)$ & $-1.02(0.3)$ \\
\hline & LIPRI & $414.5(0.00)$ & $13.9(0.00)$ & $12.4(0.00)$ & $6.9(0.00)$ \\
\hline & LNEC & $181.7(0.00)$ & $0.6(0.5)$ & $-0.88(0.3)$ & $0.88(0.3)^{*}$ \\
\hline & LOPP & $184.1(0.04)$ & $0.7(0.4)$ & $-0.7(0.4)$ & $1.2(0.2)^{*}$ \\
\hline & LPPR & $462.4(0.00)$ & $16.6(0.00)$ & $15.1(0.00)$ & $10.5(0.00)$ \\
\hline
\end{tabular}

Note:

OPP: improvement- driven opportunity entrepreneurial activity (\% of TEA)

NEC: necessity- driven entrepreneurial activity (\% of TEA)

IPRI: international property rights index

PPR: physical property rights

IPR: intellectual property rights

countries, in the short-run institutions are causes of entrepreneurship, and in the long-run there is a bidirectional causality between institutions and (opportunity-driven) entrepreneurship.

The reason of this finding fairly is clear. Economic growth is a long-term process and institutions also change in the long run. The opportunity-driven entrepreneurship often happen in developed economies. This finding is in the same line with Acs (2006), who only relates the opportunity-driven entrepreneurship to the economic growth.

\section{Discussion}

The empirical findings of the present study based on the results presented in Table 4, are summarized in Table 5 .

Tables 4 and 5 show that the causal relationship between institutions and entrepreneurship are different and it depends on the level of economic development of

Table 2 Pesaran CADF unit root test

\begin{tabular}{|c|c|c|c|c|c|c|}
\hline \multirow{2}{*}{$\frac{\text { Test } \rightarrow}{\text { Variables } \downarrow}$} & & \multicolumn{2}{|c|}{ With constant and trend } & \multicolumn{2}{|c|}{ With constant } & \multirow[t]{2}{*}{ Result } \\
\hline & & $\operatorname{Lag}(0)$ & $\operatorname{Lag}(1)$ & $\operatorname{Lag}(0)$ & $\operatorname{Lag}(1)$ & \\
\hline \multirow[t]{3}{*}{ Efficiency } & LIPR & $3.48(1.00)$ & $10.6(1.00)$ & $-1.5(0.06)$ & $13.7(1.00)$ & $\mathrm{I}(1)$ \\
\hline & LIPRI & $4.05(1.00)$ & $10.6(1.00)$ & $-0.5(0.29)$ & $13.7(1.00)$ & $\mid(1)$ \\
\hline & LPPR & $0.4(0.66)$ & $10.6(1.00)$ & $-0.4(0.00)$ & $13.7(1.00)$ & $\mid(1)$ \\
\hline Factor & LIPR & $4.036(1.00)$ & $6.14(1.00)$ & $0.94(.82)$ & $7.8(1.00)$ & $\mid(1)$ \\
\hline \multirow[t]{2}{*}{ Innovation } & LIPRI & $1.9(0.09)$ & $10.5(1.00)$ & $0.068(0.52)$ & $13.6(1.00)$ & $\mid(1)$ \\
\hline & LPPR & $1.9(0.9)$ & $10.5(1.00)$ & $-0.1(0.13)$ & $13.6(1.00)$ & $\mid(1)$ \\
\hline
\end{tabular}


Table 3 ADF Fisher Unit Root Test

\begin{tabular}{llll}
\hline Test $\rightarrow$ & & Level & Result \\
\hline Variables $\downarrow$ & & I(1) \\
\hline Efficiency & LNEC & $37.9(0.06)$ & I(1) \\
& LOPP & $29.3(0.29)$ & I(1) \\
Factor & LNEC & $7.4(0.48)$ & $\mid(1)$ \\
& LOPP & $8.8(0.42)$ & $\mid(1)$ \\
& LIPRI & $1.5(0.99)$ & $\mid(1)$ \\
Innovation & LPPR & $2.3(0.96)$ & $\mid(1)$ \\
& LNEC & $44(0.07)$ & $\mid(1)$ \\
& LOPP & $40.2(1.2)$ & $\mid(1)$ \\
\hline
\end{tabular}

countries, time horizons and types of entrepreneurship. Also, the hypothesis proposed by Henrekson and Sanandaji (2011) only is confirmed for innovation-driven countries and only in the long run. For other countries and in the short-run and long-run, and even in innovation-driven countries in the short-run, the bidirectional causality is not proven yet, and there is unidirectional causal relationship differently.

Based on the results of Table 5, it can be seen that in the short- run in the innovation-driven countries, institutions are causes of entrepreneurship. In some studies, in the entrepreneurship literature, countries are classified into three categories of factor-driven, efficiency-driven and innovation-driven. Also it is assumed that a unidirectional causality from institutions to entrepreneurship exists. This hypothesis that "in innovation-driven countries institutions plays an important role in encouraging entrepreneurship" had been confirmed in the studies of Aidis et al. (2008, 2009), Simon-Moya et al. (2013), Castano et al. (2015), Bjornskov and Foss (2008), and Burke and Fraser (2012). But in other studies, the result shows that the relationship between these variables is not clear. For example, Estien et al. (2013), based on data from 42 countries (mostly innovation-driven), have concluded that this relationship differs from country to country and even among homogeneous groups. Also Dau and Cuervo-Cazurra (2014) pointed to the different positive and negative impact of institutions on entrepreneurship. The common theme of all these studies is that in the

Table 4 Result of Granger Causality Test

\begin{tabular}{|c|c|c|c|c|c|c|}
\hline \multirow[t]{2}{*}{ Models } & \multicolumn{3}{|c|}{ Short run Causality } & \multicolumn{3}{|c|}{ Long run Causality } \\
\hline & Efficiency & Factor & Innovation & Efficiency & Factor & Innovation \\
\hline $\begin{array}{l}\text { Model 1: LNEC, } \\
\text { LIPR }\end{array}$ & - & - & $\begin{array}{l}\mathrm{LIPR} \rightarrow \\
\mathrm{LNEC}\end{array}$ & $\begin{array}{l}\mathrm{LIPR} \rightarrow \\
\mathrm{LNEC}\end{array}$ & - & $\begin{array}{l}\text { LIPR } \rightarrow \\
\text { LNEC }\end{array}$ \\
\hline $\begin{array}{l}\text { Model 2: LNEC, } \\
\text { LIPRI }\end{array}$ & - & ---- & - & $\begin{array}{l}\mathrm{LIPRI} \rightarrow \\
\mathrm{LNEC}\end{array}$ & - & - \\
\hline $\begin{array}{l}\text { Model 3: LNEC, } \\
\text { LPPR }\end{array}$ & $\begin{array}{l}\text { LNEC } \rightarrow \\
\text { LPPR }\end{array}$ & - & - & $\begin{array}{l}\text { LPPR } \rightarrow \\
\text { LNEC }\end{array}$ & - & - \\
\hline $\begin{array}{l}\text { Model 4: LOPP, } \\
\text { LIPR }\end{array}$ & - & $\mathrm{LOPP} \rightarrow \mathrm{LIPR}$ & $\begin{array}{l}\mathrm{LIPR} \rightarrow \\
\mathrm{LOPP}\end{array}$ & $\begin{array}{l}\mathrm{LIPR} \rightarrow \\
\mathrm{LOPP}\end{array}$ & LOPP $\rightarrow L \mathrm{LPR}$ & LOPP ↔LIPR \\
\hline $\begin{array}{l}\text { Model 5: LOPP, } \\
\text { LIPRI }\end{array}$ & $\begin{array}{l}\text { LOPP } \rightarrow \\
\text { LIPRI }\end{array}$ & $\begin{array}{l}\text { LOPP } \rightarrow \\
\text { LIPRI }\end{array}$ & - & $\begin{array}{l}\mathrm{LIPRI} \rightarrow \\
\mathrm{LOPP}\end{array}$ & $\begin{array}{l}\text { LOPP } \rightarrow \\
\text { LIPRI }\end{array}$ & LOPP↔ LIPR \\
\hline $\begin{array}{l}\text { Model 6: LOPP, } \\
\text { LPPR }\end{array}$ & $\begin{array}{l}\mathrm{LOPP} \rightarrow \\
\mathrm{LPPR}\end{array}$ & - & - & $\begin{array}{l}\text { LPPR } \rightarrow \\
\text { LOPP }\end{array}$ & - & $\begin{array}{l}\text { LOPP } \leftrightarrow \\
\text { LPPR }\end{array}$ \\
\hline
\end{tabular}

Note: " $\rightarrow$ " stands for direction of causality 
Table 5 The Summary of Results

\begin{tabular}{llll}
\hline Country $\rightarrow$ Time Horizon $\downarrow$ & Factor-driven & Efficiency-driven & Innovation-driven \\
\hline Short-term & Entre. $\rightarrow$ Insti. & Entre. $\rightarrow$ Insti. & Insti. $\rightarrow$ Entre. \\
Long-term & Entre. $\rightarrow$ Insti. & Insti. $\rightarrow$ Entre. & Entre. $\leftrightarrow$ Insti. \\
\hline
\end{tabular}

Note: " $\rightarrow$ " stands for direction of causality

innovation-driven countries, institutions are causes of entrepreneurship in the short-run. In the present study this result is achieved. To the best knowledge of this researcher, still there is a lack of study (except Samadi, 2018) which investigates the causal relationship between the institutions and entrepreneurship. The study conducted by Samadi (2018) was for MENA countries (mostly factor-driven countries) and did not consider the level of economic development of countries.

The findings of this paper shows that institutions only are linked with the opportunity-driven entrepreneurship at all levels of economic development, and this is consistent with the findings of Reddy (2012). But the direction of causality relationship at different levels of economic development in the short and long term is different. There is no clear result in the short term, but in the efficiency-driven countries the H1 hypothesis and in the factor-driven countries $\mathrm{H} 2$ hypothesis has been accepted in the long term. Factor driven countries are countries that suffer from the inadequate institutional status (high corruption, poor protection of property rights, inadequate support for entrepreneurship, etc.). Therefore, these opportunity-driven entrepreneurs especially are the political entrepreneurs who can make changes in the existing institutional quality (Samadi, 2018). The situation of the efficiency-driven countries is the contrary to these countries, and so these results are acceptable. In innovation-driven countries there is a bidirectional causality between institutions and entrepreneurship in long-run. Therefore, the hypothesis (H3) proposed by Henrekson and Sanandaji (2011) only is accepted in innovation-driven countries in long-run.

For two reasons, one can defense these conclusions:

1. The change in institutions is very slow in the short-run, and only one may expect the institutional changes occur in a long-run. Although events such as revolutions and coups, etc. ... can lead to fundamental changes in institutions in the short-run, but this is not the case here and it is assumed that changes occur in a quiet political space.

2. In order to entrepreneurs be able to resolve the inefficiency of the institutions, society should have a minimum level of institutional quality. These minimums are ever present in the innovation-driven countries. It's a fact that entrepreneurs are able to create new opportunities and create new conditions for political, institutional and policy entrepreneurs and they lead to institutional changes. Institutional changes require suitable institutional quality that only such institutions exist in innovation-driven countries and in long-run.

\section{Concluding remarks}

There is a rich literature on the factors affecting entrepreneurship. These factors are differing and depending on the level and types (or nature) of entrepreneurship, the level of analysis, the level of economic development of the countries, and the time horizons. In many studies, the factors influencing entrepreneurship in a group of countries have been studied, but in few studies it has been considered in three categories of 
factor-driven, efficiency-driven and innovation-driven countries. In most of the studies, the institutional environment is an important determinant of the level and types (or nature) of entrepreneurship, thus, it is suggested improving the institutional quality to improve the entrepreneurship. Noteworthy is the fact that in former studies unidirectional causality was assumed from the institutions to the entrepreneurship. However as mentioned earlier, entrepreneurs are important and are causes of institutional changes. Therefore, at the outset, the relationship between institutions and entrepreneurship should be determine, and then modeling is done. This article seeks to fill this gap in applied research.

By using the panel Granger-type causality test, this relationship has been examined among the factor-driven, efficiency-driven and innovation-driven countries. According to the acquired results, the direction of causality is different in the short-run and long-run, also the direction of causality varies among factor-driven, efficiency-driven and innovation-driven countries. Based on the findings of this paper, policymakers to encourage entrepreneurs should consider the developmental level of the country and carry out different plans in short-run and long-run.

According to the available literature on entrepreneurship, the following points can be considered in future studies:

1- In the present study regarding to the limitation of data (small length of period and lack of data in a country level), only the panel Granger-type causality test was used. Since there is a S-shaped relationship between the level of economic development and entrepreneurial activities by considering the institutional issues, therefore nonlinear behavior exists (Reddy, 2012, p.13), in the case of access to more data, the nonlinear panel causality tests can be used.

2- One of the findings of the present study is that there is bidirectional causality between entrepreneurship and institutions in innovation-driven countries in the long run. To further explore this finding, these countries can be classified according to the study of Acs and Szerb (2009) into three categories of Leaders, followers, and challengers, and apply linear and nonlinear causality tests to investigate the causality relationship between variables in the short term and Long term.

3- Due to the use of specific indicators (due to lack of data), the findings of this study should be considered with caution. The present study suggests that the empirical studies should investigate at the different analysis levels (macro, firm, and individual level) with an especial type of entrepreneurship and a specific type of institution and this causality relationship will investigate accuracy.

\section{Endnotes}

${ }^{1}$ In 2008, Global Entrepreneurship Monitor, based on Michael Porter's theory of economic development, the countries categorized in to three categories of factor-driven, efficiency-driven and innovation-driven economies. Given this categorization, it is possible to compare countries at the economic development level as well as the same geographic regions.

${ }^{2}$ Middle East and North Africa (MENA)

${ }^{3}$ Organization for Economic Co-operation and Development (OECD)

${ }^{4}$ www.gemconsortium.org 
${ }^{5}$ Guatemala, Iran, Jamaica and Uganda.

${ }^{6}$ Argentina, Bosnia and Herzegovina, Brazil, Chile, China, Colombia, Croatia, Ecuador, Hungary, Latvia, Malaysia, Mexico, Peru, Romania, Russia, South Africa, Turkey and Uruguay.

${ }^{7}$ Belgium, Denmark, Finland, France, Germany, Greece, Ireland, Italy, Japan, Korea, Netherlands, Norway, Slovenia, Spain, Sweden, Switzerland, United Kingdom and the United States.

${ }^{8}$ The time period is based on the availability of data.

${ }^{9}$ All calculations are done on the Stata 12 software.

${ }^{10}$ Here the results due to lack of space are not reported and are available to the author.

Abbreviations

ADF: Augmented Dickey-Fuller; CADF: Cross-section Augmented Dickey-Fuller; ECT: Error Correction Term; Entre: Entrepreneurship; Insti: Quality of Institutions; MENA: Middle East and North Africa; OECD: Organization for Economic Co-operation and Development; PVAR: Panel Vector Autoregressive; PVECM: Panel Vector Error Correction Model

Acknowledgements

I am grateful to Prof. Dr. Nezameddin Faghih for suggestion studying in this area.

Funding

No funding was received.

Availability of data and materials

All data's extracted form GEM and WB websites.

Authors' contributions

The author read and approved the final manuscript.

Ethics approval and consent to participate

Not applicable.

\section{Consent for publication}

Not applicable.

Competing interests

The author declares that he has no competing interests.

\section{Publisher's Note}

Springer Nature remains neutral with regard to jurisdictional claims in published maps and institutional affiliations.

Received: 18 June 2018 Accepted: 27 November 2018

Published online: 04 January 2019

References

Acemoglu, D., Johnson, S., Robinson, J., \& Thaicharoen, Y. (2003). Institutional causes, macroeconomic symptoms: Volatility, crises and growth. Journal of Monetary Economics, 50, 49-123.

Acs, Z. (2006). How is entrepreneurship good for economic growth? Innovations: Technology, Governance, Globalization, 1, 97-107.

Acs, Z., \& Szerb, L. (2009). The global entrepreneurship index (Geindex). Foundations and Trends in Entrepreneurship, 5, $341-435$.

Acs, Z. J., \& Amoros, J. E. (2008). Entrepreneurship and competitiveness dynamics in Latin America. Small Business Economics, 31(3), 305-322.

Aidis, R., Estrin, S., \& Mickiewicz, T. (2008). Institutions and entrepreneurship development in Russia: A comparative perspective. Journal of Business Venturing, 23(6), 656-672.

Aidis, R., Estrin, S., \& Mickiewicz, T. (2009). Entrepreneurial entry: Which institutions matter? IZA Discussion Paper, 4123, 2-45.

Angulo-Guerrero, M.-J., Perez-Moreno, S., \& Abad-Guerrero, I.-M. (2017). How economic freedom affect opportunity and necessity entrepreneurship in the OECD countries. Journal of Business Research, 73, 30-37.

Aparicio, S., Urbano, D., \& Audretsch, D. (2015). Institutional factors, opportunity entrepreneurship and economic growth: Panel data evidence. Technological Forecasting and Social Change, 102, 45-61.

Autio, E., \& Acs, Z. J. (2010). Intellectual property protection and the formation of entrepreneurial growth aspirations. Strategic Entrepreneurship Journal, 4(3), 234-251.

Baez, B., \& Abolafia, M. Y. (2002). Bureaucratic entrepreneurship and institutional change: A sense-making approach. Journal of Public Administration Research and Theory, 12(4), 525-552. 
Bastian B, Zali MR, Mirzaei M (2015) Institutional framework conditions and entrepreneurial attitudes and motivations. In: Nicoló D (Edi.) Start-ups and start-up ecosystems: theories, models and case studies in the Mediterranean area. ASERS Publishing, Craiova, Romania. https://doi.org/10.14505/sse.2015.ch2.

Baumol, W. J. (1990). Entrepreneurship: Productive, unproductive, and destructive. Journal of Political Economy, 98(5), 893-921. Bjerregaard, T., \& Lauring, J. (2012). Entrepreneurship as institutional change: Strategies of bridging institutional contradictions. European Management Review. https://doi.org/10.1111/j.1740-4762.2012.01026.x.

Bjornskov, C., \& Foss, N. J. (2008). Economic freedom and entrepreneurial activity: Some cross-country evidence. Public Choice, 134, 307-328 https://doi.org/10.1007/s11127-007-9229-y.

Bowen, H. P., \& De Clercq, D. (2008). Institutional context and the allocation of entrepreneurial effort. Journal of International Business Studies, 39(4), 747-767.

Breitung, J., \& Pesaran, M. H. (2005). Unit roots and cointegration in panels. Deutsche Bundesbank discussion paper series 1: Economic studies, No 42/2005.

Brixiova, Z., \& Egert, B. (2017). Entrepreneurship, institutions and skills in low-income countries. Economic Modelling, 67, $381-391$. https://doi.org/10.1016/j.econmod.2017.02.020.S.

Burke, A., \& Fraser, S. (2012). Self-employment: The role of intellectual property right laws. Small Business Economics, 39, 819-833.

Busenitz, L. W., Gómez, C., \& Spencer, W. J. (2000). Country institutional profiles: Unlocking entrepreneurial phenomena. The Academy of Management Journal, 43(5), 994-1003.

Castano, M. S., Mendez, M. T., \& Galindo, M. A. (2015). The effect of social, cultural, and economic factors on entrepreneurship. Journal of Business Research, 68(7), 1496-1500

Dau, L. A., \& Cuervo-Cazurra, A. (2014). To formalize or not to formalize: Entrepreneurship and pro-market institutions. Journal of Business Venturing, 29(5), 668-686.

Dedigama, A. C., \& Fellow, H. D. S. (2009). International property rights index (IPRI): 2009 report. Comdok.

El Harbi, S., \& Anderson, A. R. (2010). Institutions and the shaping of different forms of entrepreneurship. The Journal of SocioEconomics, 39(3), 436-444

Elert, N., Henrekson, M., \& Stenkula, M. (2017). Institutional reform for innovation and entrepreneurship: An agenda for Europe, Springer Open.

Estrin, S., Korosteleva, J., \& Mickiewicz, T. (2013). Which institutions encourage entrepreneurial growth aspirations? Journal of Business Venturing, 28(4), 564-580

Fuentelsaz, L., González, C., \& Maicas, J. P. (2018). Formal institutions and opportunity entrepreneurship: The contingent role of informal institutions. Business Research Quarterly. https://doi.org/10.1016/j.brq.2018.06.002.

Fuentelsaz, L., Gonzalez, C., Maicas, J. P., \& Montero, J. (2015). How different formal institutions affect opportunity and necessity entrepreneurship. Business Research Quarterly, 18(4), 246-258.

Greener, I. (2009). Entrepreneurship and institution-building in the case of childminding. Work, Employment \& Society, 23(2), $305-322$.

Greenwood, R., \& Suddaby, R. (2006). Institutional entrepreneurship in mature fields: The big five accounting firms. The Academy of Management Journal, 49(1), 27-48.

Henrekson, M. (2007). Entrepreneurship and institutions. In Research Institute of Industrial Economics, (IFN) (Vol. 707, pp. 1-28).

Henrekson, M., \& Sanandaji, T. (2011). The interaction of entrepreneurship and institutions. Journal of Institutional Economics, 7, 47-75

Kalantaridis, C., \& Fletcher, D. (2012). Entrepreneurship and institutional change: A research agenda. Entrepreneurship and Regional Development, 24(3/4), 199-214.

Koellinger, P., \& Minniti, M. (2009). Unemployment benefits crowd out nascent entrepreneurial activity. Economics Letters, 103(2), 96-98.

Kozul-Wright, R., \& Rayment, P. (1997). The institutional hiatus in economies in transition and its policy consequences Cambridge. Journal of Economics, 21(5), 641-661.

Kuchavr, P. (2015). Entrepreneurship and institutional change: The case of surrogate motherhood. Journal of Evolutionary Economics https://doi.org/10.1007/s00191-015-0433-5.

Lee, S.-H., Peng, M. W., \& Barney, J. B. (2007). Bankruptcy law and entrepreneurship development: A real options perspective. The Academy of Management Review, 32(1), 257-272.

Levie, J., \& Autio, E. (2008). A theoretical grounding and test of the GEM model. Small Business Economics, 31(3), $235-263$.

Li, D. D., Feng, F., \& Jiang, H. (2006). Institutional entrepreneurs. American Economic Review, 96(2), 358-362.

Majbouri, M. (2016). Oil and entrepreneurship. Energy Policy, 94, 10-15.

Mitchell, D. T., \& Campbell, N. D. (2009). Corruption's effect on business venturing within the United States. The American Journal of Economics and Sociology, 68(5), 1135-1152.

Muralidharan, E., \& Pathak, S. (2016). Informal institutions and international entrepreneurship. International Business Review https://doi.org/10.1016/j.ibusrev.2016.07.006.

North, D. C. (1990). Institutions, institutional change and economic performance. Cambridge: University Press.

Nystrom, K. (2008). The institutions of economic freedom and entrepreneurship: Evidence from panel data. Public Choice, 136(3/4), 269-282

Otahal, T. (2012). Institutional entrepreneurship: Productive or destructive? Available at SSRN 2003747, 1-30.

Pesaran, M. H. (2003). A simple panel unit root test in the presence of cross section dependence, Working paper. Cambridge: Trinity College.

Pesaran, M. H. (2004). General diagnose tests for cross section dependence in panels, Working paper. Cambridge: Trinity College.

Reddy, C. D. (2012). Entrepreneur Institutions and Economic Development: A Configurational Approach, Unpublished Dissertation, University of Cape Town.

Samadi, A. H. (2008). Property rights and economic growth: An endogenous growth model. Dissertation, Isfahan University, Isfahan, Iran: Unpublished Ph.D.

Samadi, A. H. (2018). Institutions and Entrepreneurship in MENA Countries. In N. Faghih \& M. R. Zali (Eds.), Entrepreneurship Ecosystem in the Middle East and North Africa (MENA), Springer International Publishing AG (part of Springer Nature) https:// doi.org/10.1007/978-3-319-75913-5_3. 
Sambharya, R., \& Musteen, M. (2014). Institutional environment and entrepreneurship: An empirical study across countries. Journal of Institutional Entrepreneurship, 12(4), 314-330.

Simon-Moya, V., Revuelto-Taboada, L., \& Guerrero, R. F. (2013). Institutional and economic drivers of entrepreneurship: An international perspective. Journal of Business Research, 67(5), 715-721.

Sobel, R. S. (2008). Testing Baumol: Institutional quality and the productivity of entrepreneurship. Journal of Business Venturing, 23(6), 641-655.

Spencer, J. W., \& Gomez, C. (2004). The relationship among national institutional structures, economic factors, and domestic entrepreneurial activity: A multi-country study. Journal of Business Research, 57(10), 1098-1107.

Stenholm, P., Acs, Z. J., \& Wuebker, R. (2013). Exploring country-level institutional arrangements on the rate and type of entrepreneurial activity. Journal of Business Venturing, 28, 176-193.

Stephen, F. H., Urbano, D., \& van Hemmen, S. (2005). The impact of institutions on entrepreneurial activity. Managerial and Decision Economics, 26(7), 413-419.

Troilo, M. (2011). Legal institutions and high-growth aspiration entrepreneurship. Economic Systems, 35(2), 158-175.

Urbano, D., \& Alvarez, C. (2014). Institutional dimensions and entrepreneurial activity: An international study. Small Business Economics, 42(4), 703-716.

Valdez, M. E., \& Richardson, J. (2013). Institutional determinants of macro-level entrepreneurship. Entrepreneurship Theory and Practice, 37(5), 1149-1175.

Wennekers, S., \& Thurik, R. (1999). Linking entrepreneurship and economic growth. Small Business Economics, 13(1), 27-55.

Wennekers, S., Van Wennekers, A., Thurik, R., \& Reynolds, P. (2005). Nascent entrepreneurship and the level of economic development. Small Business Economics, 24(3), 293-309.

Westlund, H., \& Bolton, R. (2003). Local social capital and entrepreneurship, Special Issue on Entrepreneurship, Firm Growth and Regional Development in the New Economic Geography. Small Business Economics, 21(2), 77-113.

Williams, N., \& Vorley, T. (2015). Institutional asymmetry: How formal and informal institutions affect entrepreneurship in Bulgaria. International Small Business Journal, 33(8), 840-861.

Youssef, A. B., Boubaker, S., \& Omri, A. (2018). Entrepreneurship and sustainability: The need for innovation and institutional solutions. Technological Forecasting and Social Change, 129, 232-241.

Yu, T.-F. (2001). An entrepreneurship perspective of institutional change. Journal of Constitutional Political Economy, 12, 217-236.

\section{Submit your manuscript to a SpringerOpen ${ }^{\circ}$ journal and benefit from:}

- Convenient online submission

- Rigorous peer review

- Open access: articles freely available online

- High visibility within the field

- Retaining the copyright to your article

Submit your next manuscript at $\boldsymbol{\nabla}$ springeropen.com 